Published in final edited form as:

J Acquir Immune Defic Syndr. 2015 July 1; 69(3): e85-e92. doi:10.1097/QAI.0000000000000634.

\title{
Effects of CD4 monitoring frequency on clinical endpoints in clinically stable HIV-infected patients with viral suppression
}

\author{
Jin Young Ahn, MD ${ }^{1}$, David Boettiger, MPharm, MSc $^{2}$, Matthew Law, MSc, PhD $^{2}$, \\ Nagalingeswaran Kumarasamy, MD, MBBS, $\mathrm{PhD}^{3}$, Evy Yunihastuti, MD, $\mathrm{PhD}^{4}$, Romanee \\ Chaiwarith, MD, MHS ${ }^{5}$, Man Po Lee, MBBS ${ }^{6}$, Benedict LH Sim, MBBS, MRCP7 , Shinichi \\ Oka, MD, PhD $^{8}$, Wingwai Wong, MD $^{9}$, Adeeba Kamarulzaman, MBBS, FRACP, FAMM, \\ FASc $^{10}$, Pacharee Kantipong, MD ${ }^{11}$, Praphan Phanuphak, MD, PhD ${ }^{12}$, Oon Tek Ng, MBBS, \\ MRCP, MPH ${ }^{13}$, Sasisopin Kiertiburanakul, MD, MHS ${ }^{14}$, Fujie Zhang, MD ${ }^{15}$, Sanjay Pujari, \\ MD ${ }^{16}$, Rossana Ditangco, MD ${ }^{17}$, Winai Ratanasuwan, MD ${ }^{18}$, Tuti Parwati Merati, MD, PhD ${ }^{19}$, \\ Vonthanak Saphonn, MD, MSc, PhD ${ }^{20}$, Annette H. Sohn, MD ${ }^{21}$, Jun Yong Choi, MD, PhD ${ }^{1,}$, \\ and on behalf of the TREAT Asia HIV Observational Databases (TAHOD)
}

\begin{abstract}
${ }^{1}$ Department of Internal Medicine and AIDS Research Institute, Yonsei University College of Medicine, Seoul, Korea ${ }^{2}$ The Kirby Institute, UNSW Australia, Sydney, Australia ${ }^{3}$ Chennai Antiviral Research and Treatment Clinical Research Site (CART CRS), YRGCARE Medical Centre, VHS, Chennai, India ${ }^{4}$ Working Group on AIDS Faculty of Medicine, University of Indonesia, Cipto Mangunkusumo Hospital, Jakarta, Indonesia ${ }^{5}$ Research Institute for Health Sciences, Chiang Mai, Thailand ${ }^{6}$ Queen Elizabeth Hospital, Hong Kong, China ${ }^{7}$ Hospital Sungai Buloh, Sungai Buloh, Malaysia ${ }^{8}$ National Center for Global Health and Medicine, Tokyo, Japan ${ }^{9}$ Taipei Veterans General Hospital, Taipei, Taiwan ${ }^{10}$ University Malaya Medical Centre, Kuala
\end{abstract}

\footnotetext{
*Corresponding author: Jun Yong Choi Department of Internal Medicine and AIDS Research Institute, Yonsei University College of Medicine, 50 Yonsei-ro, Seodaemun-gu, Seoul 120-752, Korea. Tel: +82-2-2228-1974, Fax: +82-2-393-6884, seran@ yuhs.ac.

Conflicts of Interest:

There is no relevant financial interests between any author and any company in this manuscript.

The TREAT Asia HIV Observational Database

CV Mean, V Saphonn* and K Vohith, National Center for HIV/AIDS, Dermatology and STDs, Phnom Penh, Cambodia; FJ Zhang*, HX Zhao and N Han, Beijing Ditan Hospital, Capital Medical University, Beijing, China; MP Lee*, PCK Li, W Lam, and YT Chan, Queen Elizabeth Hospital, and KH Wong, Integrated Treatment Centre, Hong Kong, China; N Kumarasamy*, S Saghayam and C Ezhilarasi, Chennai Antiviral Research and Treatment Clinical Research Site (CART CRS), YRGCARE Medical Centre, VHS, Chennai, India; S Pujari*, K Joshi and A Makane, Institute of Infectious Diseases, Pune, India; TP Merati*‡, DN Wirawan and F Yuliana, Faculty of Medicine Udayana University and Sanglah Hospital, Bali, Indonesia; E Yunihastuti*†, D Imran and A Widhani, Working Group on AIDS Faculty of Medicine, University of Indonesia/Cipto Mangunkusumo Hospital, Jakarta, Indonesia; S Oka*, J Tanuma and T Nishijima, National Center for Global Health and Medicine, Tokyo, Japan; JY Choi*, Na S and JM Kim, Division of Infectious Diseases, Department of Internal Medicine, Yonsei University College of Medicine, Seoul, South Korea; BLH Sim*, YM Gani, and R David, Hospital Sungai Buloh, Sungai Buloh, Malaysia; A Kamarulzaman*, SF Syed Omar, S Ponnampalavanar, I Azwa, N Huda, and LY Ong, University of Malaya Medical Centre, Kuala Lumpur, Malaysia; R Ditangco*, E Uy and R Bantique, Research Institute for Tropical Medicine, Manila, Philippines; WW Wong*, WW Ku and PC Wu, Taipei Veterans General Hospital, Taipei, Taiwan; OT Ng*, PL Lim, LS Lee and PS Ohnmar, Tan Tock Seng Hospital, Singapore; P Phanuphak*, K Ruxrungtham, A Avihingsanon, P Chusut, and S Sirivichayakul, HIV-NAT/Thai Red Cross AIDS Research Centre, Bangkok, Thailand; S Kiertiburanakul*, S Sungkanuparph, L Chumla and N Sanmeema, Faculty of Medicine Ramathibodi Hospital, Mahidol University, Bangkok, Thailand; R Chaiwarith*, T Sirisanthana W Kotarathititum, and J Praparattanapan, Research Institute for Health Sciences, Chiang Mai University, Chiang Mai, Thailand; P Kantipong* and P Kambua, Chiangrai Prachanukroh Hospital, Chiang Rai, Thailand; W Ratanasuwan* and R Sriondee, Faculty of Medicine, Siriraj Hospital, Mahidol University, Bangkok, Thailand; VK Nguyen*, VH Bui and TT Cao, National Hospital for Tropical Diseases, Hanoi, Vietnam; TT Pham*, DD Cuong and HL Ha, Bach Mai Hospital, Hanoi, Vietnam; AH Sohn*, N Durier*, B Petersen, and T Singtoroj, TREAT Asia, amfAR - The Foundation for AIDS Research, Bangkok, Thailand; DA Cooper, MG Law*, A Jiamsakul* and DC Boettiger, The Kirby Institute, UNSW Australia, Sydney, Australia.
} 
Lumpur, Malaysia ${ }^{11}$ Chiangrai Prachanukroh Hospital, Chiang Rai, Thailand ${ }^{12}$ HIV-NAT/Thai Red Cross AIDS Research Centre, Bangkok, Thailand ${ }^{13}$ Tan Tock Seng Hospital, Singapore ${ }^{14}$ Faculty of Medicine Ramathibodi Hospital, Mahidol University, Bangkok, Thailand ${ }^{15}$ Beijing Ditan Hospital, Capital Medical University, Beijing, China ${ }^{16}$ Institute of Infectious Diseases, Pune, India ${ }^{17}$ Research Institute for Tropical Medicine, Manila, Philippines ${ }^{18}$ Faculty of Medicine, Siriraj Hospital, Mahidol University, Bangkok, Thailand ${ }^{19}$ Faculty of Medicine Udayana University \& Sanglah Hospital, Bali, Indonesia ${ }^{20}$ National Center for HIV/AIDS, Dermatology \& STDs, and University of Health Sciences, Phnom Penh, Cambodia ${ }^{21}$ TREAT Asia, amfAR - The Foundation for AIDS Research, Bangkok, Thailand

\section{Abstract}

Background-Current treatment guidelines for HIV infection recommend routine CD4+ lymphocyte (CD4) count monitoring in patients with viral suppression. This may have a limited impact on influencing care as clinically meaningful CD4 decline rarely occurs during viral suppression.

Methods-In a regional HIV observational cohort in the Asia-Pacific, patients with viral suppression ( 2 consecutive viral loads $<400$ copies $/ \mathrm{mL}$ ) and a CD4 count 2200 cells $/ \mu \mathrm{L}$ who had CD4 testing 6 monthly were analyzed. Main study endpoints were occurrence of one CD4 count $<200$ cells $/ \mu \mathrm{L}$ (single CD4<200) and two CD4 counts $<200$ cells $/ \mu \mathrm{L}$ within a 6 -month period (confirmed CD4<200). A comparison of time to single and confirmed CD4<200 with biannual or annual CD4 assessment was performed by generating a hypothetical group comprised of the same patients with annual CD4 testing by removing every second CD4 count.

Results-Among 1538 patients, the rate of single CD4<200 was 3.45/100 patient-years, and of confirmed CD4<200 was $0.77 / 100$ patient-years. During 5 years of viral suppression, patients with baseline CD4 200-249 cells/ $\mu \mathrm{L}$ were significantly more likely to experience confirmed CD4<200 compared with patients with higher baseline CD4 (hazard ratio 55.47 [95\% confidence interval 7.36-418.20], $\mathrm{p}<0.001$ versus baseline CD4 $2500 \mathrm{cells} / \mu \mathrm{L})$. Cumulative probabilities of confirmed CD4 $<200$ was also higher in patients with baseline CD4 200-249 cells/ $\mu \mathrm{L}$ compared with patients with higher baseline CD4. There was no significant difference in time to confirmed CD4<200 between biannual and annual CD4 measurement $(\mathrm{p}=0.336)$.

Conclusions-Annual CD4 monitoring in virally suppressed HIV patients with a baseline CD4 $\geq 250$ cells $/ \mu \mathrm{L}$ may be sufficient for clinical management.

\section{Keywords}

HIV infection; HIV suppression; CD4 count; CD4 monitoring

\section{Introduction}

During the course of human immunodeficiency virus (HIV) infection, the CD4+ T lymphocyte (CD4) count is the main surrogate marker for immune function and the strongest predictor of disease progression. ${ }^{1,2}$ Initiation of antiretroviral therapy (ART) has improved the prognosis of HIV infection by increasing the CD4 count with a concomitant 
decline in the risk of opportunistic diseases. ${ }^{3,4}$ The extent of long-term immunologic recovery is affected by the baseline CD4 count at the beginning of ART ${ }^{5-7}$ US guidelines have recommended that CD4 monitoring should be performed every 3-6 months to determine when to start ART in untreated patients to assess the immunologic response to ART and the need for initiation or discontinuation of prophylaxis for opportunistic infections. ${ }^{8}$

However, CD4 count provides limited information in clinically stable, virally suppressed patients on ART because the CD4 response to ART varies widely, ${ }^{9,10}$ and a poor CD4 response is rarely an indication for modifying a virologically effective ART regimen. ${ }^{8}$ Many studies show that a decline in CD4 during ART provides unreliable evidence of virologic failure or drug resistance. ${ }^{4,11,12}$ Therefore, current national treatment programs that recommend CD4 testing every 6 to 12 months in clinically stable, virally suppressed patients may be an unnecessary use of resources.

Recently, there have been several reports confirming that a clinically meaningful CD4 decline rarely occurs during viral suppression. $., 10,13-18$ According to Gale et al., ${ }^{14}$ patients with a baseline CD4 count $>300$ cells $/ \mu \mathrm{L}$ had a 97\% probability of maintaining CD4 >200 cells $/ \mu \mathrm{L}$ for 4 years during viral suppression. Considering these results, less frequent or clinically driven CD4 testing may be warranted during viral suppression. To further address this issue, we aimed to determine rates and predictors of a CD4 cell count $<200$ cells $/ \mu \mathrm{L}$ and to determine the effects of the frequency of CD4 monitoring on clinical endpoints in in an Asian cohort of virally suppressed patients.

\section{Methods}

\section{1) Study population}

Data from the TREAT Asia HIV Observational Database (TAHOD), a prospective, observational cohort study of adults with HIV from 21 sites in the Asia-Pacific region, were analyzed. The detailed structure of TAHOD and its mechanisms of data collection have been previously described. ${ }^{19}$ Briefly, each site enrolls 100 to $450 \mathrm{HIV}$-infected patients, both treated and untreated with ART, and biannually transfers deidentified clinical and outcomes data to a central data management and biostatistical analysis center. Ethics approvals were obtained from all participating sites, the analysis center (Kirby Institute, UNSW Australia), and the coordinating center (TREAT Asia/amfAR, Bangkok). Written informed consent was not sought unless required by a site's local institutional review board. Informed consent was waived at some sites as information is collected via an anonymous case report form. All study procedures were developed in accordance with the revised 1975 Helsinki Declaration. Patients who met the following criteria were eligible for inclusion in the analysis: (1) receiving ART $>6$ months with $\geq 3$ antiretroviral agents, (2) confirmed viral suppression defined as two consecutive viral load measurements $<400$ copies/mL and a CD4 count $\geq 200$ cells $/ \mu \mathrm{L}$ after viral suppression, all within a 390-day period, and (3) a minimum of one subsequent viral load measurement $<400$ copies $/ \mathrm{mL}$ at least 12 months after confirmed viral suppression. Follow-up time was only counted when virally suppressed patients had CD4 count monitoring every 6 months. A break in regular CD4 count testing resulted in censoring. A 3-month window on either side of the 6-monthly CD4 cell count date was used. 
Patients may have had more than one CD4 count measurement within this period, but only the measurement closest to the 6-month date was considered.

\section{2) Collected data and definitions}

Study endpoints were (1) the occurrence of a single CD4 count $<200$ cells $/ \mu \mathrm{L}$ (single CD4<200), (2) confirmed CD4 count $<200$ cells $/ \mu L$ (confirmed CD4<200), or (3) clinical failure during the patient's first recorded period of viral suppression. Confirmed CD4<200 was defined as two separate $\mathrm{CD} 4$ counts $<200$ cells $/ \mu \mathrm{L}$ within a 6 -month period considering all CD4 counts within the 6 months, and clinical failure was defined as a new or recurrent WHO stage 3 or 4 illness or death.

Data included age, sex, mode of HIV exposure, hepatitis B and C serology, history of prior AIDS diagnosis, and ART regimen. AIDS-defining illnesses were defined according to the modified $1993 \mathrm{CDC}$ definitions ${ }^{20}$. Baseline was defined as the date of confirmed viral suppression.

\section{3) Statistical analysis}

Rates and predictors of single CD4<200, confirmed CD4<200, and clinical failure were analyzed by Kaplan-Meier curves and Cox regression stratified by study site. Time-to-event was measured from the date of confirmed viral suppression (i.e., date of second viral load $<400$ copies $/ \mathrm{mL}$ ) until the first single $\mathrm{CD} 4<200$, confirmatory $\mathrm{CD} 4<200$, or clinical failure event. If the last biannual CD4 count was $<6$ months prior to an ART class change or a final viral load measurement of $<400$ copies $/ \mathrm{mL}$, then time to censoring was measured from date of confirmed viral suppression until date of ART class change or final viral load $<400$ copies $/ \mathrm{mL}$ (whichever occurred first). If the last biannual CD4 count occurred $>6$ months before an ART class change or a final viral load of $<400$ copies $/ \mathrm{mL}$, then time to censoring was measured from date of confirmed viral suppression until 6 months after the final biannual CD4 count. ART class change was defined as a substitution or cessation of $\geq 1$ antiretroviral drug class in the regimen being used at the beginning of viral suppression. Predictors used in the multivariate model were selected based on a significance level of $\$$ ).10 in the univariate analyses. Predictors were retained in the multivariate model if one or more categories exhibited a p-value $₫ \mathbf{} 0.05$.

Because the study population consisted of patients with biannual CD4 cell counts, a hypothetical comparison group comprised of exactly the same patients with annual CD4 count measurement was generated by removing every second CD4 cell count from the first biannual measurement onwards. This allowed comparisons of the time-to-detection of single CD4 $<200$ and confirmed CD4 $<200$ within the study population when different rates of CD4 monitoring were applied. The effect of CD4 monitoring frequency on time to single CD4 $<200$ and confirmed CD4 $<200$ was evaluated using Kaplan-Meier estimates. Stata statistical software (version 12.1; StataCorp, College Station, TX, USA) was used for all statistical analysis. 


\section{Results}

From September 2003 to March 2013, a total of 8,493 patients were enrolled in TAHOD, of whom 7,041 had a record of more than 6 months of ART. Among them, 3,601 had documentation of confirmed viral suppression with CD 4 cell count $\geq 200$ cells $/ \mu \mathrm{L}, 1,538$ of these fulfilled the inclusion criteria with at least 6-monthly CD4 monitoring. The demographics and characteristics of the patients are shown in Table 1. The median age at the time of viral suppression was 39.9 years [interquartile range (IQR) 34.6-46.3] and the patients were predominantly male $(73.1 \%)$. Heterosexual contact was the most common risk exposure $(62.3 \%)$, and $42.8 \%$ of the patients had a prior AIDS diagnosis. Median baseline CD4 count was 393 cells/ $\mu$ L (IQR 291-536). Patients were classified into 5 groups according to baseline CD4 count: 2500 cells $/ \mu \mathrm{L}, 30.4 \%$; 350-499 cells $/ \mu \mathrm{L}, 29.8 \% ; 300-349$ cells/ $\mu \mathrm{L}, 12.5 \% ; 250-299$ cells/ $\mu \mathrm{L}, 13.5 \%$; and $200-249$ cells/ $\mu \mathrm{L}, 13.8 \%$.

We examined the change in mean CD4 count over time, stratified by baseline CD4 count (Figure 1). During viral suppression, mean CD4 gradually increased and reached a plateau after 48 months, regardless of baseline CD4 count. At each analysis interval during followup, mean CD4 count was higher in the group with a higher baseline CD4 count. When the baseline CD4 count was $\geq 250$ cells $/ \mu \mathrm{L}$, the mean CD4 count after 48 months was $>400$ cells/ $\mu \mathrm{L}$.

The overall rate of single CD4<200 was 3.45 per 100 patient-years ( $95 \%$ confidence interval [CI], 2.91-4.09). The rate of confirmed CD4<200 was 0.77 per 100 patient-years (95\% CIs, 0.57-1.09). The rate of clinical failure was 0.57 per 100 patient-years (95\% CIs, 0.38-0.85). Univariate and multivariate analyses investigated factors associated with confirmed CD4<200. Baseline CD4 count of 200-249 cells/ $\mu \mathrm{L}$ was significantly associated with confirmed CD4<200 (hazard ratio 55.47, CIs 7.36-418.20, p <0.001- compared with baseline CD4 >500). There was no significantly increased risk when baseline CD4 count was $>250$ cells $/ \mu \mathrm{L}$. HIV exposure via injecting drugs was significantly associated with risk of confirmed CD4<200 (hazard ratio 7.54, CI 1.15-49.52, p=0.035) compared with HIV exposure via heterosexual contact. Prior AIDS diagnosis was associated with confirmed CD4<200 in the univariate analysis, but not in the multivariate analysis (Table 2). Sex and ART regimen were not associated with either CD4 outcome evaluated.

Cumulative probabilities of single and confirmed CD4<200 during viral suppression stratified by baseline CD4 count are shown in Figure 2. The differences in cumulative probabilities of single CD4 $<200$ and confirmed CD4 $<200$ between patients with biannual CD4 measurement (Figures 2a and 2b) and patients with the hypothetical annual CD4 measurement (Figures $2 \mathrm{c}$ and $2 \mathrm{~d}$ ) are also shown in Figure 2. For patients with a baseline CD4 count of 200-249 cells $/ \mu \mathrm{L}$, the probability of single and confirmed CD4<200 at year 5 was $45.42 \%$ and $13.78 \%$ with biannual CD4 measurement and $28.64 \%$ and $10.25 \%$ with annual CD4 measurement, respectively. However, patients with baseline CD 2250 cells $/ \mu \mathrm{L}$ had much lower probability of single CD4<200, and rarely had confirmed CD $4<200$ in both biannual and annual measurement. When measuring CD4 count annually, there was a significantly slower time to detection of single CD4<200 (log-rank $<0.001$ ). For confirmed CD4 $<200$, there was no significant difference between biannual and annual CD4 
measurements (log-rank=0.336). The risks of clinical failure were very low for all subjects with baseline CD4 cell count $\geq 200$ cells/ $\mu \mathrm{L}$, regardless of stratified baseline CD4 counts (Figure 3).

\section{Discussion}

In general, CD4 cell counts tend to increase and remain stable in patients with viral suppression on ART. ${ }^{21-23}$ In this context, there have been studies questioning the clinical usefulness of frequent CD4 testing, demonstrating that clinically meaningful CD4 decline rarely occurs in virally suppressed and clinically stable patients. In 2002, Phillips et al. reported that only 5 of 166 patients showed a decline in CD4 $<350$ cells $/ \mu \mathrm{L}$ over 47 weeks among virally suppressed patients with baseline CD4 $>500$ cells $/ \mu \mathrm{L} .{ }^{13}$ Similar results have subsequently been reported. ${ }^{14-16}$ The definition of a clinically meaningful CD4 decline in two studies was CD4 $<200$ cells $/ \mu \mathrm{L}$, because individuals with CD4 $<200$ cells $/ \mu \mathrm{L}$ are at higher risk of opportunistic infection and need prophylaxis for Pneumocystis jiroveci pneumonia. ${ }^{14,16}$ In these studies, to define the threshold of an immunologically stable status, the rate of CD4 decline was stratified by baseline CD4 cell count. Each study showed that individuals with baseline CD4 2350 cells $/ \mu \mathrm{L}^{16}$ and CD4 2300 cells $/ \mu \mathrm{L}^{14}$ had a very low risk of subsequent CD4 decline.

Similarly, several previous studies have showed that patients with baseline CD4 $<300$ cells $/ \mu \mathrm{L}$ had a significantly increased risk of clinically meaningful CD4 declines under 200 cells/ $\mu \mathrm{L}$ than patients with higher baseline CD $4 .{ }^{14,17,18}$ In the present study, patients with baseline CD4 $<250$ cells $/ \mu \mathrm{L}$ had a $13.8 \%$ probability of confirmed CD4<200 after 5 years, while the same probability was $1.6 \%$ at a baseline CD4 of $250-299$ cells $/ \mu \mathrm{L}, 1.6 \%$ for 300349 cells $/ \mu \mathrm{L}$, and $0.3 \%$ for 3350 cells $/ \mu \mathrm{L}$. In the multivariate analysis, baseline CD4 <250 cells $/ \mu \mathrm{L}$ was associated with a significantly greater risk of confirmed $\mathrm{CD} 4<200$ during virological suppression. However, there was no association when baseline CD4 was higher. To our knowledge, baseline CD4 of 250 cells $/ \mu \mathrm{L}$ is the lowest value defining immunologically stable status that has been reported.

In contrast to confirmed $C D 4<200$, the cumulative probability of single $C D 4<200$ was higher even in patients with baseline CD4 250 cells/ $\mu \mathrm{L}$. In several studies, endpoints were single CD4 decline or single CD4 value of the lowest CD4 count. ${ }^{13,14,16,17}$ However, the clinical significance of single CD4 decline is doubtful. Because there are various non-HIVrelated causes of CD4 decline such as acute illness or CD4-lowering treatments like trimethoprim-sulfamethoxazole, chemotherapy or interferon. ${ }^{8,24}$ Physiologic variation can also lead to a transient CD4 decline. One study reported physiologic CD4 variation around a median of 119 cells $/ \mu \mathrm{L}$ ranged from 35 to 395 cells $/ \mu \mathrm{L}$ over 2 weeks. ${ }^{25}$ According to Gale et al., 24 of 61 patients with a CD4 decline of $<200$ cells $/ \mu \mathrm{L}$ during viral suppression had an alternative reason causing non-HIV CD4 lymphopenia, and subsequent examination showed some of those patients had steady CD4 increases after the decline. ${ }^{14}$ The study of Ford et al. also showed that $97 \%$ of cases with a single CD4<200 during HIV suppression had CD4 recovery above this value in follow-up testing. ${ }^{17}$ Considering these points, it is difficult to regard the category of single $\mathrm{CD} 4<200$ as a meaningful CD4 decline. We were unable to identify other studies of the clinical significance of two consecutive CD4 values $<200$ 
cells $/ \mu \mathrm{L}$ in comparison to a single CD4 value of $<200$ cells $/ \mu \mathrm{L}$ during HIV infection. However, we believe that two consecutive CD4 measurements $<200$ cells $/ \mu \mathrm{L}$ indicate sustained CD4 decline and better represents HIV-related CD4 lymphopenia. When annual and biannual CD4 monitoring were compared, the cumulative probability of confirmed CD4<200 did not show a statistically significant difference. This suggests that less frequent CD4 measurement does not miss important immunological events in patients with viral suppression.

Less frequent CD4 monitoring in virally suppressed patients also has some benefits. First, this would initiate potential cost savings. According to Hyle et al., reducing CD4 monitoring in stable patients from biannually to annually would save \$10.2 million per year in United States. ${ }^{9}$ Another benefit is to reduce patient anxiety regarding transient declines in CD4, which can otherwise lead to additional testing. In the present study, the cumulative probability of detecting a single CD4 $<200$ was lower when measured annually compared to biannually, indicating that less frequent CD4 testing may be a reasonable management approach.

Meanwhile, the results of this study demonstrated that the risk of clinical failure during viral suppression was very low for all HIV suppressed patients with baseline CD4 200 cells/ $\mu \mathrm{L}$. There were only 23 events during total 4,057 patient-years without any case of death. This result is relevant to the results of previous studies. The ARTEMIS trial showed that the HIV suppressed patients with CD4 $\geq 200$ cells/ $\mu \mathrm{L}$ had lower risk of developing AIDS-defining events than patients with $\mathrm{CD} 4<200$ cells/ $\mu \mathrm{L}$ or without viral suppression during 1 year of follow up after initiating ART. ${ }^{26}$ Similarly, in a German HIV cohort study, patients who had viral suppression but CD4<200 cells/ $\mu \mathrm{L}$ after 1 year of ART had significantly higher rates of AIDS progression than the patients with higher CD4 counts. ${ }^{27}$ In our study, the event rate of clinical failure was very low regardless of baseline CD4 once the value increased to $>200$ cells $/ \mu \mathrm{L}$. Besides, the time to detect the occurrence of clinical failure would not be changed by CD4 measurement frequency. So these results can also support less frequent CD4 monitoring without concerns of missing the clue for clinical failure when CD4 is measured annually.

There were several limitations to our study. First, the definition of viral suppression was two consecutive viral load measurements of $<400$ copies $/ \mathrm{mL}$, which is based on the viral load testing thresholds over the history of the cohort. However, current testing platforms are able to test at levels of $<20$ or $<50$ copies $/ \mathrm{mL}$, meaning that patients without viral suppression by some standards may have been included in the analysis. Second, the observational nature of our database does not permit assessment of whether documented CD4 declines are related to specific events, medications, or other interventions.

In spite of these limitations, this is the first multicenter analysis in the Asia-Pacific of the clinical utility of frequent CD4 monitoring in patients with viral suppression. And our primary endpoint is focused on the occurrence of confirmed CD4<200 which might be more clinically meaningful than single CD4<200. Furthermore, patients with baseline CD4 250299 cells $/ \mu \mathrm{L}$, who were not regarded as immunologically stable in previous studies, are demonstrated not to have additional risk of confirmed CD4<200 during viral suppression. 
Finally, our study supports less frequent CD4 monitoring by statistical analysis comparing two different CD4 testing intervals.

In conclusion, CD4 testing at 6-month intervals offered no benefit over annual testing in detecting confirmed CD4 $<200$ cells $/ \mu \mathrm{L}$. Patients with baseline CD4 250 cells $/ \mu \mathrm{L}$ had much lower risk of two consecutive CD4 $<200$ cells $/ \mu \mathrm{L}$ during viral suppression compared with patients with baseline CD4 200-249 cells/ $\mu \mathrm{L}$. Therefore, annual CD4 monitoring in virally suppressed HIV patients with a baseline CD4 $\geq 250$ cells/ $\mu \mathrm{L}$ may be sufficient for clinical management.

\section{Acknowledgments}

The TREAT Asia HIV Observational Database is an initiative of TREAT Asia, a program of amfAR, The Foundation for AIDS Research, with support from the U.S. National Institutes of Health's National Institute of Allergy and Infectious Diseases, Eunice Kennedy Shriver National Institute of Child Health and Human Development, and National Cancer Institute, as part of the International Epidemiologic Databases to Evaluate AIDS (IeDEA; U01AI069907), and the Dutch Ministry of Foreign Affairs through a partnership with Stichting Aids Fonds. The Kirby Institute is funded by the Australian Government Department of Health and Ageing, and is affiliated with the Faculty of Medicine, UNSW Australia (The University of New South Wales). JYC involvement was supported by the Basic Science Research Program through the National Research Foundation of Korea (NRF) funded by the Ministry of Education, Science and Technology (NRF-2013R1A1A2005412) and BioNano HealthGuard Research Center funded by the Ministry of Science, ICT, and Future Planning of Korea as a Global Frontier Project (Grant H-GUARD_2013M3A6B2078953). The content of this publication is solely the responsibility of the authors and does not necessarily represent the official views of any of the government or institutions mentioned above.

Sources of Funding: NIH grants IeDEA; U01AI069907; Dutch Ministry of Foreign Affairs through a partnership with Stichting Aids Fonds, Australian Government Department of Health and Ageing

\section{References}

1. Egger M, May M, Chene G, et al. Prognosis of HIV-1-infected patients starting highly active antiretroviral therapy: a collaborative analysis of prospective studies. Lancet. 2002; 360:119-129. [PubMed: 12126821]

2. Mellors JW, Munoz A, Giorgi JV, et al. Plasma viral load and CD4+ lymphocytes as prognostic markers of HIV-1 infection. Ann Intern Med. 1997; 126:946-954. [PubMed: 9182471]

3. Battegay M, Nuesch R, Hirschel B, et al. Immunological recovery and antiretroviral therapy in HIV-1 infection. Lancet Infect Dis. 2006; 6:280-287. [PubMed: 16631548]

4. Maggiolo F, Leone S. CD4+ T lymphocyte recovery in individuals with type 1 human immunodeficiency virus infection. Clin Infect Dis. 2010; 51:465-467. [PubMed: 20597689]

5. Garcia F, de Lazzari E, Plana M, et al. Long-term CD4+ T-cell response to highly active antiretroviral therapy according to baseline CD4+ T-cell count. J Acquir Immune Defic Syndr. 2004; 36:702-713. [PubMed: 15167289]

6. Mocroft A, Phillips AN, Gatell J, et al. Normalisation of CD4 counts in patients with HIV-1 infection and maximum virological suppression who are taking combination antiretroviral therapy: an observational cohort study. Lancet. 2007; 370:407-413. [PubMed: 17659333]

7. Khanna N, Opravil M, Furrer H, et al. CD4+ T cell count recovery in HIV type 1-infected patients is independent of class of antiretroviral therapy. Clin Infect Dis. 2008; 47:1093-1101. [PubMed: 18783328]

8. Panel on Antiretroviral Guidelines for Adults and Adolescents: guidelines for the use of antiretroviral agents in HIV-1-infected adults and adolescents. Department of Health and Human Services; 2014.

9. Hyle EP, Sax PE, Walensky RP. Potential savings by reduced CD4 monitoring in stable patients with HIV receiving antiretroviral therapy. JAMA Intern Med. 2013; 173:1746-1748. [PubMed: 23978894] 
10. Sax PE. Editorial commentary: can we break the habit of routine CD4 monitoring in HIV care? Clin Infect Dis. 2013; 56:1344-1346. [PubMed: 23315314]

11. Reynolds SJ, Nakigozi G, Newell K, et al. Failure of immunologic criteria to appropriately identify antiretroviral treatment failure in Uganda. AIDS. 2009; 23:697-700. [PubMed: 19209067]

12. Rawizza HE, Chaplin B, Meloni ST, et al. Immunologic criteria are poor predictors of virologic outcome: implications for HIV treatment monitoring in resource-limited settings. Clin Infect Dis. 2011; 53:1283-1290. [PubMed: 22080121]

13. Phillips AN, Youle M, Lampe F, et al. CD4 cell count changes in individuals with counts above 500 cells/mm and viral loads below 50 copies/ml on antiretroviral therapy. AIDS. 2002; 16:10731075. [PubMed: 11953476]

14. Gale HB, Gitterman SR, Hoffman HJ, et al. Is frequent CD4+ T-lymphocyte count monitoring necessary for persons with counts $>=300$ cells/muL and HIV-1 suppression? Clin Infect Dis. 2013; 56:1340-1343. [PubMed: 23315315]

15. Whitlock GG, Ahmed N, Benn P, et al. Stop routine CD4 monitoring in HIV-infected patients with fully suppressed virus and CD4 >=350 cells/ml. Clin Infect Dis. 2013; 57:327-328. [PubMed: 23537910]

16. Stephan C, Hill A, Xi N, et al. Research letter: is monitoring for CD4 counts still needed for the management of patients with long-term HIV RNA suppression? J Acquir Immune Defic Syndr. 2012; 61:e73-75. [PubMed: 23183153]

17. Ford N, Stinson K, Davies MA, et al. Is it safe to drop CD4+ monitoring among virologically suppressed patients: a cohort evaluation from Khayelitsha, South Africa. AIDS. 2014; 28:20032005. [PubMed: 25102088]

18. Duncan CJ, Schmid ML, Schwab U, et al. Futility of CD4+ monitoring in HIV-1 patients with CD4+ cell count above 350 cells/mul on suppressive antiretroviral therapy. AIDS. 2014; 28:26382639. [PubMed: 25418545]

19. Zhou J, Kumarasamy N, Ditangco R, et al. The TREAT Asia HIV Observational Database: baseline and retrospective data. J Acquir Immune Defic Syndr. 2005; 38:174-179. [PubMed: 15671802]

20. 1993 revised classification system for HIV infection and expanded surveillance case definition for AIDS among adolescents and adults. MMWR Recomm Rep. 1992; 41:1-19.

21. Goetz MB, Boscardin WJ, Wiley D, et al. Decreased recovery of CD4 lymphocytes in older HIVinfected patients beginning highly active antiretroviral therapy. AIDS. 2001; 15:1576-1579. [PubMed: 11504992]

22. Staszewski S, Miller V, Sabin C, et al. Determinants of sustainable CD4 lymphocyte count increases in response to antiretroviral therapy. AIDS. 1999; 13:951-956. [PubMed: 10371176]

23. Viard JP, Mocroft A, Chiesi A, et al. Influence of age on CD4 cell recovery in human immunodeficiency virus-infected patients receiving highly active antiretroviral therapy: evidence from the EuroSIDA study. J Infect Dis. 2001; 183:1290-1294. [PubMed: 11262215]

24. Feeney C, Bryzman S, Kong L, et al. T-lymphocyte subsets in acute illness. Crit Care Med. 1995; 23:1680-1685. [PubMed: 7587233]

25. Raboud JM, Montaner JS, Conway B, et al. Variation in plasma RNA levels, CD4 cell counts, and p24 antigen levels in clinically stable men with human immunodeficiency virus infection. J Infect Dis. 1996; 174:191-194. [PubMed: 8655993]

26. Girard PM, Nelson M, Mohammed P, et al. Can we stop CD4+ testing in patients with HIV-1 RNA suppression on antiretroviral treatment? AIDS. 2013; 27:2759-2763. [PubMed: 23842127]

27. Zoufaly A, an der Heiden M, Kollan C, et al. Clinical outcome of HIV-infected patients with discordant virological and immunological response to antiretroviral therapy. J Infect Dis. 2011; 203:364-371. [PubMed: 21208929] 
Mean CD4 cell count over time by baseline CD4 category

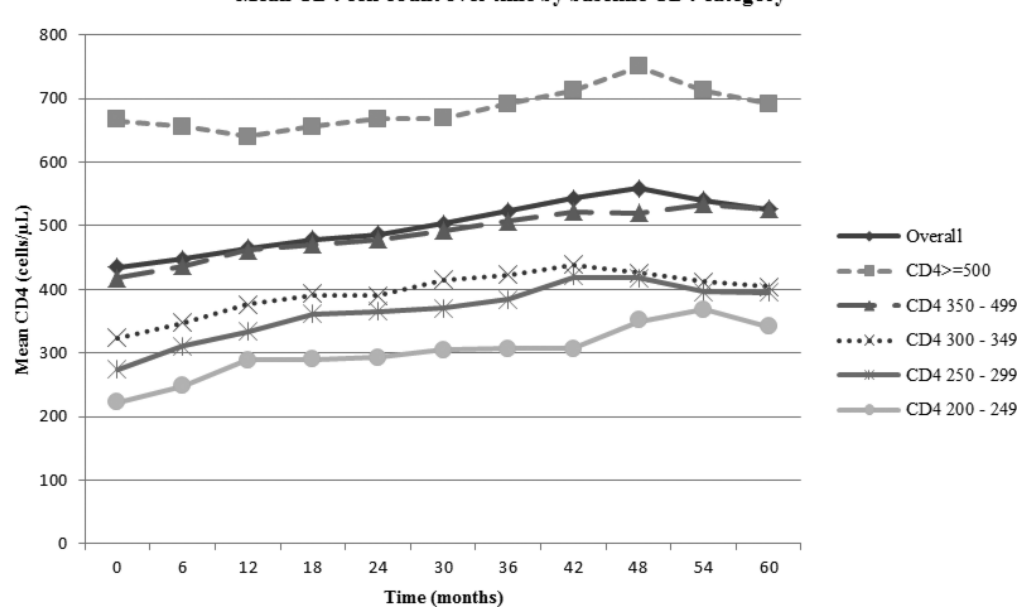

Figure 1.

Mean CD4 cell count during viral suppression by baseline CD4 category. 

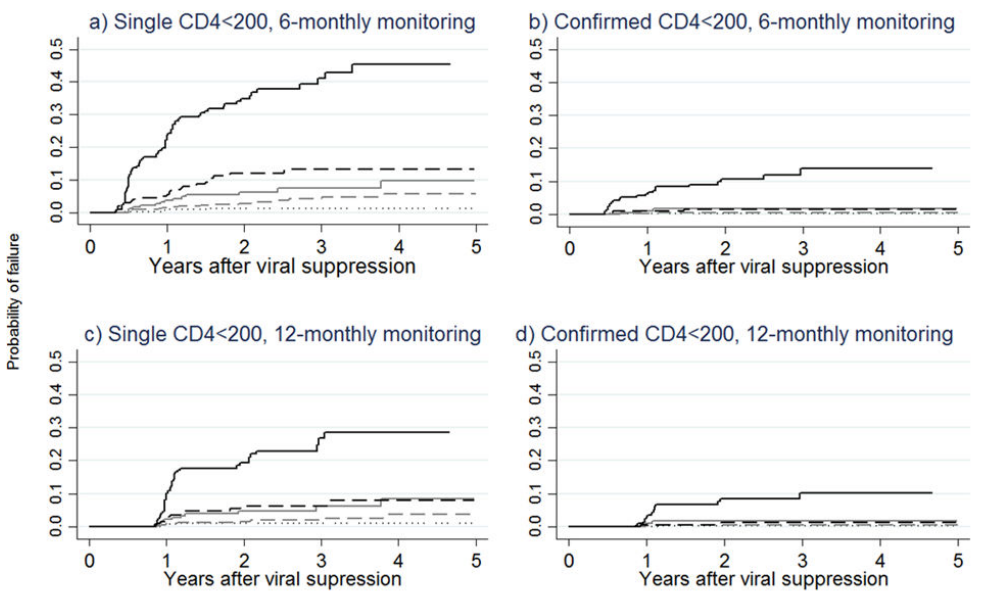

CD4 $>500--\operatorname{CD} 4350-499-\operatorname{CD} 4300-349--\operatorname{CD} 4250-299-\operatorname{CD} 4200-249$

Figure 2.

Cumulative probabilities during viral suppression of a) single CD4<200 with 6-monthly monitoring by baseline CD4 count, b) confirmed CD4<200 with 6-monthly monitoring by baseline CD4 count, c) single CD4<200 with 12-monthly monitoring by baseline CD4 count, d) confirmed CD4<200 with 12-monthly monitoring by baseline CD4 count. 


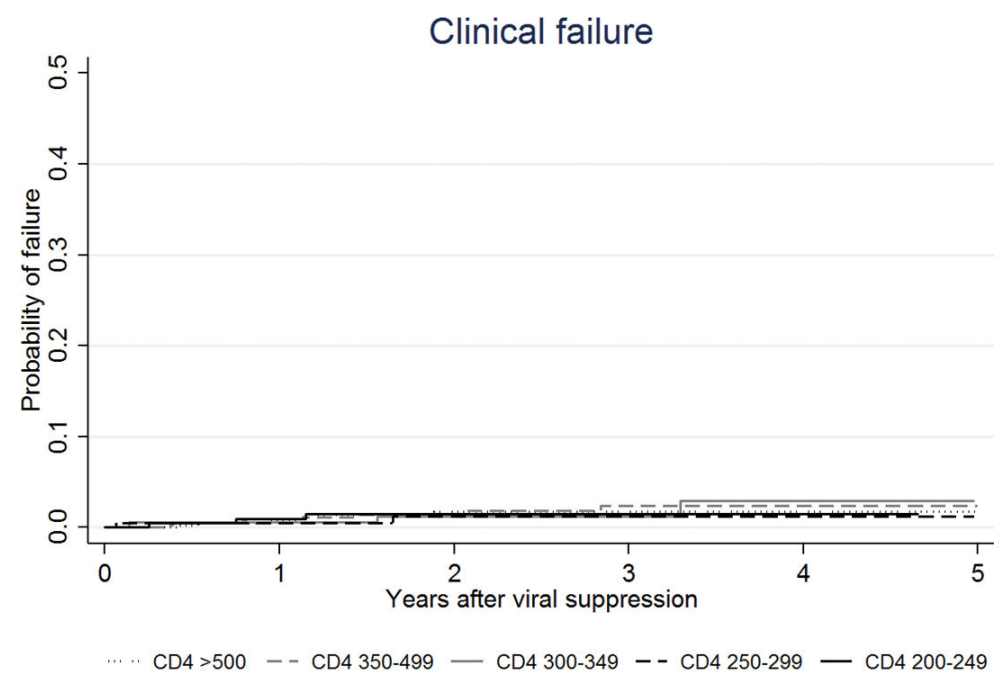

Figure 3.

Cumulative probabilities during viral suppression of clinical failure by baseline CD4 count 


\section{Table 1}

\section{Baseline patient characteristics}

\begin{tabular}{|c|c|}
\hline Variables & Total $\mathrm{N}=1538 \mathrm{~N}(\%)$ \\
\hline \multicolumn{2}{|l|}{ Age, years } \\
\hline Median (IQR) & $39.9(34.6-46.3)$ \\
\hline$₫ 30$ & $156(10.1)$ \\
\hline $31-40$ & $624(40.6)$ \\
\hline $41-50$ & $505(32.8)$ \\
\hline$>50$ & $253(16.4)$ \\
\hline \multicolumn{2}{|l|}{ Sex } \\
\hline Male & $1124(73.1)$ \\
\hline Female & $414(26.9)$ \\
\hline \multicolumn{2}{|l|}{ HIV exposure } \\
\hline Heterosexual & $958(62.3)$ \\
\hline Homosexual & $445(28.9)$ \\
\hline Injecting drug use & $31(2.0)$ \\
\hline Other/unknown & $104(6.8)$ \\
\hline \multicolumn{2}{|l|}{ Prior AIDS diagnosis } \\
\hline None known & $879(57.2)$ \\
\hline Yes & $659(42.8)$ \\
\hline \multicolumn{2}{|l|}{ HBV co-infection } \\
\hline Negative & $1233(80.2)$ \\
\hline Positive & $144(9.4)$ \\
\hline Not tested & $161(10.5)$ \\
\hline \multicolumn{2}{|l|}{ HCV co-infection } \\
\hline Negative & 1249 (81.2) \\
\hline Positive & $83(5.4)$ \\
\hline Not tested & $206(13.4)$ \\
\hline \multicolumn{2}{|c|}{ CD4 cell count, cells/ $\mu \mathrm{L}$} \\
\hline Median (IQR) & $393(291-536)$ \\
\hline 2500 & $467(30.4)$ \\
\hline $350-499$ & $459(29.8)$ \\
\hline $300-349$ & $193(12.5)$ \\
\hline $250-299$ & $207(13.5)$ \\
\hline $200-249$ & $212(13.8)$ \\
\hline \multicolumn{2}{|l|}{ ART regimen } \\
\hline NRTI + NNRTI & $1145(74.4)$ \\
\hline $\mathrm{NRTI}+\mathrm{PI}$ & $373(24.3)$ \\
\hline Other combination & $20(1.3)$ \\
\hline
\end{tabular}

ART, antiretroviral therapy; HBV, hepatitis B virus; $\mathrm{HCV}$, hepatitis C virus; IQR, interquartile range; NRTI, nucleoside reverse transcriptase inhibitor; NNRTI, non-nucleoside reverse transcriptase inhibitor; PI, protease inhibitor. 
Table 2

Baseline predictors of confirmed CD4 cell count $<200$ cells/ $\mu \mathrm{L}$ during virological suppression

\begin{tabular}{|c|c|c|c|c|c|c|c|c|}
\hline Predictors & Confirmed CD4<200 cells $/ \mu \mathrm{L}$ & $\begin{array}{l}\text { Rate per } 100 \\
\text { patient-years } \\
(95 \% \text { CIs })\end{array}$ & $\begin{array}{c}\text { Univariate HR } \\
\text { (95\% CIs) }\end{array}$ & p value & p overall & $\begin{array}{l}\text { Multivariate }{ }^{¥} \text { HR } \\
\text { (95\% CIs) }\end{array}$ & p value & p overall \\
\hline \multicolumn{9}{|l|}{ Age, years } \\
\hline$\unlhd 30$ & 1 & $0.26(0.04-1.84)$ & 1.00 & & & 1.00 & & \\
\hline $31-40$ & 10 & $0.61(0.33-1.13)$ & $2.90(0.36-23.61)$ & 0.319 & & $2.34(0.29-18.77)$ & 0.425 & \\
\hline $41-50$ & 13 & $0.95(0.55-1.63)$ & $4.53(0.56-36.53)$ & 0.156 & & $2.76(0.35-21.96)$ & 0.337 & \\
\hline$>50$ & 7 & $1.09(0.52-2.29)$ & $4.18(0.48-36.53)$ & 0.196 & $0.137^{\dagger}$ & $2.67(0.30-23.77)$ & 0.378 & $0.436^{\dagger}$ \\
\hline \multicolumn{9}{|l|}{ Sex } \\
\hline Male & 26 & $0.86(0.59-1.27)$ & 1.00 & & & 1.00 & & \\
\hline Female & 5 & $0.49(0.20-1.17)$ & $0.53(0.19-1.48)$ & 0.223 & & $0.84(0.29-2.48)$ & 0.755 & \\
\hline \multicolumn{9}{|l|}{ HIV exposure } \\
\hline Heterosexual & 16 & $0.64(0.39-1.05)$ & 1.00 & & & 1.00 & & \\
\hline Homosexual & 9 & $0.73(0.38-1.41)$ & $1.03(0.35-3.05)$ & 0.956 & & $1.21(0.43-3.39)$ & 0.723 & \\
\hline Injecting drug use & 2 & $3.08(0.77-12.33)$ & $5.11(0.97-27.03)$ & 0.055 & & $7.54(1.15-49.52)$ & 0.035 & \\
\hline Other/unknown & 4 & $1.60(0.60-4.27)$ & $3.61(1.04-12.56)$ & 0.043 & $0.06^{*}$ & $2.86(0.78-10.47)$ & 0.112 & $0.110^{*}$ \\
\hline \multicolumn{9}{|l|}{ Prior AIDS diagnosis } \\
\hline None known & 13 & $0.57(0.33-0.98)$ & 1.00 & & & 1.00 & & \\
\hline Yes & 18 & $1.02(0.65-1.63)$ & $2.16(1.02-4.58)$ & 0.045 & & $1.37(0.64-2.94)$ & 0.425 & \\
\hline \multicolumn{9}{|l|}{ HBV co-infection } \\
\hline Negative & 21 & $0.65(0.43-1.00)$ & 1.00 & & & 1.00 & & \\
\hline Positive & 7 & $1.69(0.80-3.54)$ & $2.17(0.87-5.39)$ & 0.096 & & $1.82(0.72-4.61)$ & 0.208 & \\
\hline Not tested & 3 & $0.74(0.24-2.29)$ & - & & & - & & \\
\hline \multicolumn{9}{|l|}{ HCV co-infection } \\
\hline Negative & 23 & $0.68(0.45-1.03)$ & 1.00 & & & 1.00 & & \\
\hline Positive & 3 & $1.53(0.49-4.74)$ & $2.08(0.62-7.03)$ & 0.237 & & $1.34(0.36-5.01)$ & 0.661 & \\
\hline Not tested & 5 & $1.07(0.44-2.57)$ & - & & & - & & \\
\hline \multicolumn{9}{|l|}{$\begin{array}{l}\text { CD4 cell count, } \\
\text { cells } / \mu \mathrm{L}\end{array}$} \\
\hline 2500 & 1 & $0.08(0.01-0.55)$ & 1.00 & & & 1.00 & & \\
\hline $350--499$ & 2 & $0.16(0.04-0.65)$ & $1.87(0.17-20.78)$ & 0.609 & & $2.04(0.18-22.65)$ & 0.561 & \\
\hline $300--349$ & 3 & $0.58(0.19-1.79)$ & $6.78(0.70-65.90)$ & 0.099 & & $7.22(0.74-70.29)$ & 0.089 & \\
\hline 250--299 & 3 & $0.56(0.18-1.73)$ & $6.80(0.70-66.48)$ & 0.100 & & $6.96(0.71-67.92)$ & 0.095 & \\
\hline 200--249 & 22 & $4.67(3.08-7.10)$ & $54.13(7.17-408.57)$ & $<0.001$ & $<0.001^{\dagger}$ & $55.47(7.36-418.20)$ & $<0.001$ & $<0.001^{\dagger}$ \\
\hline \multicolumn{9}{|l|}{ ART regimen } \\
\hline NRTI + NNRTI & 20 & $0.69(0.44-1.07)$ & 1.00 & & & 1.00 & & \\
\hline NRTI + PI & 10 & $0.93(0.50-1.74)$ & $1.86(0.64-5.40)$ & 0.251 & & $2.39(0.75-7.59)$ & 0.138 & \\
\hline Other combination & 1 & $1.81(0.26-12.87)$ & $3.66(0.44-30.09)$ & 0.228 & $0.334^{\frac{t}{t}}$ & $1.71(0.19-14.97)$ & 0.629 & $0.331^{*}$ \\
\hline
\end{tabular}

All models stratified by site. Significant multivariate p-values are bolded.

${ }^{¥}$ Adjusted for predictors of confirmed CD4 count $<200$ included in the final model (HIV exposure group and baseline CD4 cell count) 
${ }^{\dagger} \mathrm{p}$ overall for linear trend

* overall for heterogeneity. ART, antiretroviral therapy; CI, confidence interval; $\mathrm{HR}$, hazard ratio; $\mathrm{HBV}$, hepatitis B virus; $\mathrm{HCV}$, hepatitis $\mathrm{C}$ virus; $\mathrm{HR}$, hazards ratio; NRTI, nucleoside reverse transcriptase inhibitor; NNRTI, non-nucleoside reverse transcriptase inhibitor; PI, protease inhibitor. 